\title{
Integration of Sustainable Value Stream Mapping (Sus. VSM) and Life-Cycle Assessment (LCA) to Improve Sustainability Performance

\author{
Taufik Djatna $^{\# 1}$, Dwi Prasetyo ${ }^{\# 2}$ \\ ${ }^{\#}$ Postgraduate Program of Agro Industrial Engineering, IPB University, Bogor, 16680, Indonesia \\ E-mail: ${ }^{1}$ taufikdjatna@ipb.ac.id, ${ }^{2}$ dwiprasetyo123@gmail.com
}

\begin{abstract}
Sustainable manufacturing concept is adopted by many stakeholders for its framework, on considering environmental, social, and economic aspect, called as triple-bottom-line (TBL). It concerns the future of manufacturing review on sustainability and requires deeper evaluation on TBL and product life cycle as well as to see the environmental impact at process stage. In this work, a proposed Sustainable Value Stream Mapping (Sus-VSM) as an extended traditional VSM considers integration with Life-Cycle Assessment (LCA) to assess current condition in addition to analyze future sustainability improvement at a food based manufacturing. The current state presented all metrics associated with the TBL of manufacturing metrics. Calculation of critical metrics using the Borda Count Method (BCM) showed that speed-loss, total defect product, and heat loss were critical and chosen for further analysis. Analysis using 5 Whys analysis showed that the problems were mainly caused by the unstable material condition, the problem of filling area machinery, and operator disciplinary. Process life-cycle assessment was performed using Simapro v. 8.0 with single score cooking and cleaning. It obtained $60700 \mathrm{Pt}$ and $108 \mathrm{Pt}$. Future improvement using Failure Mode and Effect Analysis (FMEA) proposed and could reduce lead time from 4967.46 seconds to 4759.17 seconds, cleaning time from 2.8 hours to 2.14 hours, and total defect product from $4.85 / \mathrm{batch}$ to $2.82 \mathrm{~kg} / \mathrm{batch}$. Future improvement on steam performance proposed and could reduce the total single score of cooking and cleaning to $59500 \mathrm{Pt}$ and $102 \mathrm{Pt}$.
\end{abstract}

Keywords - sustainable value stream mapping; life-cycle assessment; failure mode and effect analysis; speed loss; total defect product; heat loss.

\section{INTRODUCTION}

Sustainable manufacturing concept has been increasingly adopted by many company stakeholders. Its framework by considering three different aspects such as environment, social and economic concerns the future of natural resources and human life [1]. According to [2], sustainable manufacturing is a system that integrates product and process design issues with issues of manufacturing, planning, and control to identify, quantify, assess, and manage the flow of environmental waste with the goal of reducing the environmental impact while also trying to maximize resource efficiency. The three different aspects of sustainable manufacturing called as triple-bottom-line (TBL). The bottom lines cover economic aspect as the measure of how the processes can give maximum profit and the minimum loss (corporate profit account), societal aspect as a consideration of how social organization responsibility contributes to the whole operation effectiveness (people account), and environmental aspect as the measure of how environmentally responsible it has been. TBL overview helps companies look not only on the economic value that they generate, but also it makes it possible to incorporate environmental and societal values into the assessment of their activities [3].

In this regard, the implementation of a sustainable concept by adopting suitable Value Stream Mapping (VSM), a tool in lean manufacturing to identify waste, has been proposed. The lean concept is a primary system to improve operational performance by addressing three issues that are fundamental: eliminate waste, remove variability, and improve throughput. VSM, according to [4], defined as a mapping of all the actions, both value added and non-value added required to bring a product through the production flow from raw material until finished-product. However, the conventional VSM methodology only examines the economic constraints which are captured as time-basis evaluation (cycle time, lead time, idle time, etc.) and does not account for environmental and societal performance. Reference [5] suggested sustainable VSM (Sus-VSM) evaluate sustainability performance that follows the TBL perspective. The indicators from TBL is incorporated into suitable Sus-VSM metrics with a case study at the satellite television dishes manufacturing firm. Suitable metrics were identified using 
visual symbols as a preliminary analysis of sustainability performance.

Further manufacturing review is taken on the environmental metric to give further sustainable performance evaluation. An integration method of Sus-VSM and Life cycle Assessment (LCA) has been proposed by [6]. LCA is an approach to assess the environmental impacts associated with a product life cycle or a service from the extraction of raw materials through to the end-of-life treatment [7]. In this research, the LCA approach is taken to evaluate environmental impacts at the process level of product creation. Environmental impacts include emissions generated into the environment through the consumption of resources, as well as during several stages of product life cycle such as collection of resources, reuse, recycle, and waste disposal. The implementation of combining LCA and Sus-VSM is pursued to allow lean improvement processes to focus on specific environmental improvement action while monitoring the environmental impacts during lean improvement initiatives [6]. The steps of Sus-VSM application are generally alike with conventional VSM, which consist of identifying of the product family and product flow, mapping the current state, analyzing for future improvement, mapping the future state, and implementing future state plan [4]. Analysis for future improvement selects critical sustainability metrics using the Borda Count Method. Failure Mode and Effect Analysis (FMEA) to arrange future improvement possibilities based on related facts. Analysis of environmental category also assessed to evaluate environmental impacts by using LCA approach. Simapro 8.0 software is used, and Eco-indicator ' 99 method to perform end-point (damage-based) impact assessment that complies with ISO 14040 standard.

Based on the explanation of the background and problem statement, the objectives research consists: (1) to identify and construct current-state of Sustainable value stream map, (2) to evaluate critical sustainability indicator and assess environmental impacts of product life cycle, and (3) to model future improvement opportunities.

\section{MATERIAL AND METHODS}

This research consisted of two main frameworks, which are the visualization \& analysis of Sustainable VSM and the assessment of life-cycle impact at the process stage. SusVSM was visualized through several steps which began with identifying the critical type of product and product flow, followed with identifying the essential sustainability metrics which are divided into economic, environmental, and societal categories (the triple bottom line of manufacturing). The sustainability metrics identified refer to Sus-VSM study which was conducted by Faulkner and Badurdeen (2014). The Fig. 1. below shows the research stage.

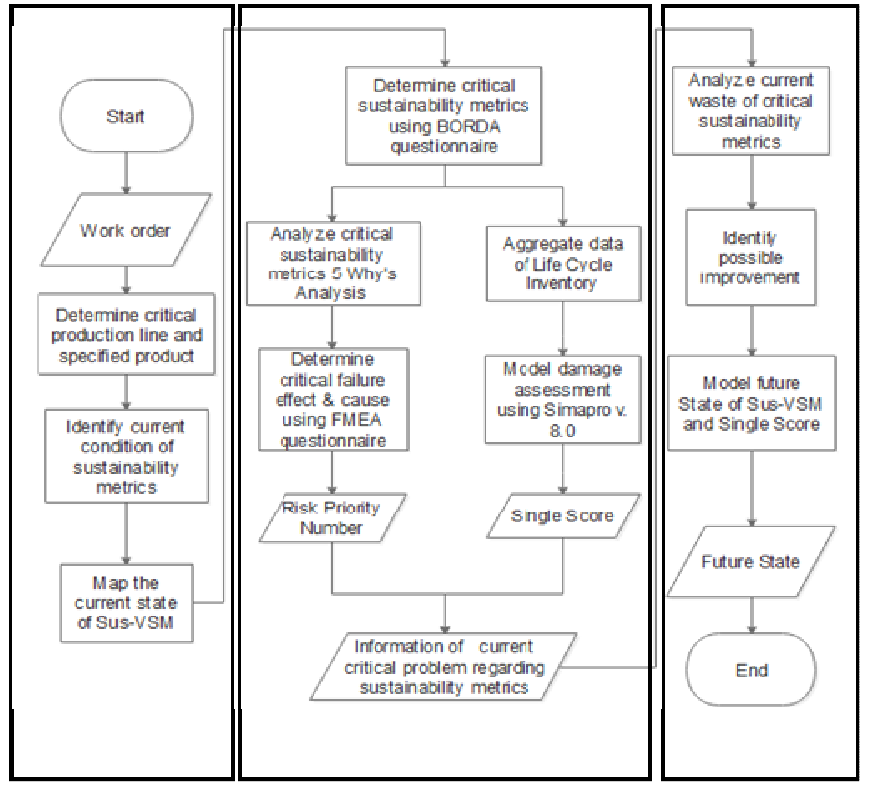

Fig. 1 Research framework

Analysis of Sus-VSM began with selecting critical sustainability metrics with the Borda Count Method (BCM) questionnaire and followed by determining the root cause of failure using 5 Whys Analysis. Risk priority was calculated by Failure Mode and Effect Analysis (FMEA) questionnaire for each failure to help finding the critical possible future improvements. Life cycle assessment began with the lifecycle inventory analysis at gate-to-gate level. The inputoutput balance was then used to model damage assessment using Simapro v. 8.0 and to obtain the single score of environmental impacts. Both outputs of the Risk Priority Number (RPN) and Single Score were used as information to analyze the solution for improvement.

\section{A. Identification of Critical Product and Product Flow}

The aim of selecting a critical product is to investigate deeply in order to draw out the current situation of information and physical flow so that the area of improvement opportunities can be measured [8]. The determination of product type is conducted by using information about the product based on the quantity of product produced, the level of demand, or the similarity of the process in production [9]. In this research, the critical product for value stream target is selected by using Work Order of 2017. Product flow was identified by direct observation through the production process. Cycle time and uptime were also measure to get more information on the production processes. Measuring cycle time helps to break down value adding time and non-value adding time so that actual time loss can be detected [10]. Cycle time each process has the following formula:

$$
\text { Cycle time }=\mathrm{VA}+\mathrm{ENVA}+\mathrm{NVA}
$$

VA = value-adding activities time (second)

ENVA = essential value-adding activities time (second)

NVA = non-value-adding activities time (second) 


\section{B. Identification of Sustainability Metrics}

Sustainable manufacturing metrics are used to evaluate the performance of manufacture from the economic, environmental, and societal perspective that are selected based on the contribution of sustainability drivers toward the manufacturing processes [6]. The sustainability metrics selected for this study are shown in Table I.

TABLE I

SELECTED SustainABLE METRICS

\begin{tabular}{|c|c|c|}
\hline Category & Metric & Description \\
\hline \multirow{2}{*}{ Economic } & $\begin{array}{l}\text { Total defect } \\
\text { product }\end{array}$ & $\begin{array}{l}\text { Defect products categorized as } \\
\text { re-workable and destroy product }\end{array}$ \\
\hline & Speed loss & $\begin{array}{l}\text { Process speed reduced due to } \\
\text { un-standard speed operation }\end{array}$ \\
\hline \multirow{4}{*}{$\begin{array}{l}\text { Environ- } \\
\text { ment }\end{array}$} & $\begin{array}{l}\text { Water } \\
\text { consumption }\end{array}$ & $\begin{array}{l}\text { Amount of water used during } \\
\text { the manufacturing process }\end{array}$ \\
\hline & $\begin{array}{l}\text { Raw material } \\
\text { usage }\end{array}$ & $\begin{array}{l}\text { The flow of material usage } \\
\text { through the process that } \\
\text { includes material added and } \\
\text { removed as scraps }\end{array}$ \\
\hline & $\begin{array}{l}\text { Power } \\
\text { consumption }\end{array}$ & $\begin{array}{l}\text { Amount of power used during } \\
\text { the manufacturing process }\end{array}$ \\
\hline & Heat loss & $\begin{array}{l}\text { Un-effective steam usage due to } \\
\text { loss through insulation system }\end{array}$ \\
\hline \multirow[t]{2}{*}{ Society } & $\begin{array}{l}\text { Physical load } \\
\text { index }\end{array}$ & $\begin{array}{l}\text { Identification of physical } \\
\text { ergonomics of the workplace on } \\
\text { each process }\end{array}$ \\
\hline & $\begin{array}{l}\text { Work } \\
\text { environmental } \\
\text { risks }\end{array}$ & $\begin{array}{l}\text { Four risk categories of work } \\
\text { environment due to: electrical } \\
\text { system, hazardous } \\
\text { chemical/material used, } \\
\text { pressurized system, and high- } \\
\text { speed components }\end{array}$ \\
\hline
\end{tabular}

\section{Determination of Critical Sustainability Metrics}

In this stage, the Borda Count Method (BCM) was used to determine critical sustainability metrics. According to BCM, first proposed by Jean-Charles de Borda, if a voter ranks the alternatives $a_{1}, \ldots, a_{m} a_{s} a_{\sigma}(1)>a_{\sigma}(2)>\ldots>a_{\sigma}(m)$ (where $\sigma$ is a permutation of $\{1 \ldots, m\}), a_{\sigma}(1)$ gets $m-1$ Borda points, $a_{\sigma}$ (2) gets $m-2$ Borda points..., $a_{\sigma}(m)$ gets 0 Borda points. The Borda score of a given alternative $a$ is the total number of Borda points given by the voters to a. The social ranking of the alternatives and the winner(s) are obtained by comparing the Borda scores of the different alternatives [12]. The general formula for each alternative is shown below:

$$
\operatorname{BMC}(a)=\sum_{i=1}^{k}(i-1) \cdot p_{i}
$$

Definition: Let $a$ be an alternative. Let $p_{i}$ be the number of voters who gave grade to a, where $i=1,2, \ldots, k$. Then we define $B C M(a):=p_{1} \cdot 0+p_{2} \cdot 1+\ldots+p_{k} \cdot(k-1)$ and call it the Borda Count Method (BCM) of a.

\section{Information}

a = alternative

$i \quad=$ borda point of each score

$p_{i} \quad=$ cardinal number of voters who gave grade to $a$

\section{Determination of Root Cause of Failure}

The identification of the cause of problems used root cause analysis (RCA) technique. RCA is a structured investigation that aims to identify the actual cause of a problem and the actions necessary to eliminate it. The 5 whys tool was used in this research as one of the RCA approach to delve more deeply into the casual relationship on each problem that occurs [12].

Failure Mode and Effect Analysis (FMEA) was performed to determine risk priority of each root cause. FMEA is used as an analytical technique that provides consideration and resolution of all possible problems that may occur during the creation of the product [12] Three considerations are made which are severity (S), occurrence (O), and detectability (D). Ranked considerations that in each varies from 1-10 was determined to obtain risk priority number (RPN). RPN is inferred as-as ranking to the rating of improvement activities and importance of problem/failure. The formula of RPN was calculated by multiplying these three number with formula as follow:

$$
R P N=S \times O \times D
$$

$\mathrm{S}=$ Severity number that considers the worst potential consequence of failure

$\mathrm{O}=$ Occurrence number that considers the likelihood of the failure occurring

$\mathrm{D}$ = Detectability number that considers the current control of solving problem's detection

\section{E. Evaluation of Life Cycle Assessment}

Life Cycle Assessment (LCA) is an environmental assessment tool that investigates potential environmental impacts of products or services through the whole life cycle [13]. In this stage, The aim of using LCA approach was to explore the environmental category of sustainability by evaluating inputs, outputs, and the potential environmental impacts so that the full assessment can evaluate the sustainability of the product. The stage of LCA according to ISO 14040 standard can be seen in the Fig. 2.

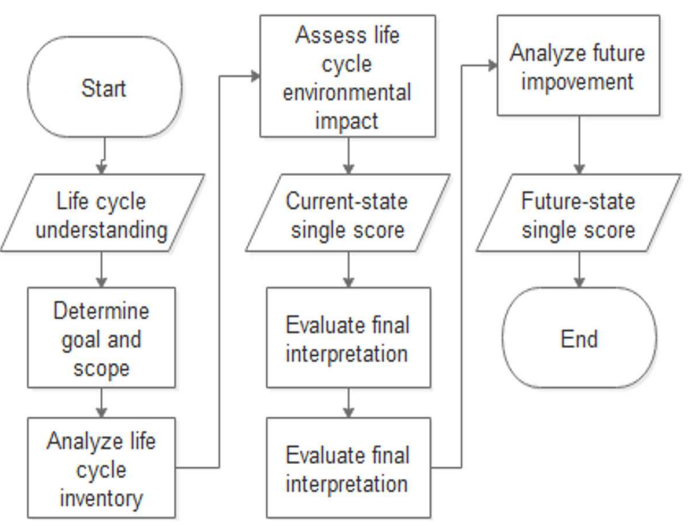

Fig. 2 Flowchart of life cycle assessment

The environmental impact assessment was modeled by using LCA software, Simapro v. 8.0. Simapro is a tool to collect, analyze, and monitor the sustainability performance data of the company's products and/or services that are 
developed by PRé Sustainability, the environmental and social impact assessment consultant. Eco-indicator '99 method was applied to perform end-point (damage-based) impact assessment that complies with ISO 14040 standard. This method assesses three damage categories, which are human health, ecosystem quality, and resources affects at the end-point that may occur during product creation activity [14].

\section{RESULT AND DISCUSSION}

\section{A. Critical Product and Product Flow}

PT $\mathrm{X}$ focuses on the production of processed cheese product. The processed cheese product focuses on processing natural cheese product (curd cheese) into more varieties of final product in term of their composition (cheese used, texture, additives, etc.) with the variation of type of portion, whether it is individual slices, rectangular blocks, cylinders, or tubes (Safriet 1997). There are four main processes that represent all production line, which are curd preparation, cooking, packaging, and packing process. From the total of six production line, A41 is selected as a value stream target since the highest production demand is found in this type of product during 2017. The cycle time summary can be seen in the Table 2 .

TABLE II

Cycle Time Of A41 Production

\begin{tabular}{|l|l|l|}
\hline No. & \multicolumn{1}{|c|}{ Process } & \multicolumn{1}{|c|}{ Cycle time (second) } \\
\hline 1. & Unwrapping & 87.67 \\
\hline 2. & Cutting & 47.33 \\
\hline 3. & Grinding & 210.67 \\
\hline 4. & Cooking & 515 \\
\hline 5. & Filling - packaging & 587.12 \\
\hline 6. & Cooling - packing & 3005 \\
\hline 7. & Palletizing & 27.34 \\
\hline \multicolumn{2}{|l|}{ Total Cycle Time } & $\mathbf{4 4 8 0 . 1 3}$ \\
\hline
\end{tabular}

Cycle time measurement is divided into seven main processes, which are unwrapping, cutting, grinding, cooking, filling - packaging, cooling - packing, and palletizing. Filling - packaging is the process that has continuous flow. Thus, the calculation of cycle time is merged into one process. This also applies the cooling - packing process. Each process is divided into activities that include operation, transportation, inspection, and delay. Transportation of moving material to the next process, as well as the waiting for WIP (Work-In-Process) activity, are calculated separately from the process. Process delay time is measured based on the Job Order data in each process.

The result shows the total cycle time for A41 is 4480.13 seconds with the lead-time is 4967.46 seconds. The whole process has VA, ENVA, and NVA of 4034.33 seconds, 772.68 seconds, and 160.45 seconds respectively. The nonvalue-adding activities measured affects the total cycle time of the process, which causes the whole process time becomes longer. The highlight focuses on three processes that causes delay, which are cooking, filling - packaging, and cooling - packing process. Delay occurred in cooking, filling - packaging, and cooling - packing are 13 seconds/batch, 12.45 seconds/batch, and 6.67 seconds/batch respectively. From the cycle time information, the filling packaging process has the current output speed of 8 products/minute. The ideal output speed determined for the process is 12 products per minute.

\section{B. Critical Sustainability Metrics}

Based on questionnaire response of five respondents from the different division, as observed that speed loss, total defect product, and heat loss are selected as critical sustainability metrics. The further analysis focused on minimizing the effect of problems occurred on mentioned metrics.

\section{1) Speed loss}

According to the result, eight cause factors contribute the whole speed loss, which are the start-finish loss, cleaning time loss, delay at cooking, time loss due to pump trouble, and delay at filling-packaging, delay at packing, power failure, and time loss due to cooling trouble. Problem due to pump trouble has been solved through the company's corrective actions. Power failure and trouble at cooling tunnel contribute the lowest value of speed loss. Thus, the focus of analysis takes into account the other causes.

Start-finish production loss means the loss that occurs before the first shift started and before the last shift ended. Every production date both starts and finishes at 06:00. The actual time of start-finish time varies, as allowance made is not controlled as punctual. Delay on process was identified in cooking, filling - packaging, and cooling- packing process. Delay in cooking occurred due to idling on removing thick blend product. Thick blend product is the product that does not meet the standard in term of its viscosity that increases before the product from the cooking area are transferred to the next process. Delay on filling - packaging process occurred due to machinery trouble that leads to the idling. Speed controller and motor on the sealer machine did not have match spare part, and it leads to the unstable sealer machine. Sealer machine often stopped, and the sensor of glue on the sealer cannot detect the product that passes through the sealer plate. Another machine trouble occurred is the coding machine that often stagnated and cannot operate properly due to the clumped ink on the sprayer. The delay on cooling - packing process occurred to the idling on conveyor issue. The conveyor often stagnated due to spare part failure and torn packaging that pass and stuck the conveyor belt.

Cleaning time reduced-speed also contribute to the speed loss. In this company, there is a regulation to manage cleaning every 48 hours. The cleaning covers wet cleaning throughout preparation area (includes cutting and grinding area), cooking area, and filling - packaging area. The current speed of cleaning is 2.8 hours/cleaning while last year the performance gained is 2.14 hours/cleaning. This can affect the production start-up time, up to 0.66 hours of reduced speed in each cleaning. The figure below shows the Pareto chart of speed loss. 


\section{2) Total Defect Product}

Identification on total defect product also highlighted the defect generated from three processes, which are cooking, filling - packaging, and cooling - packing. The defect on these processes are calculated as $1.12 \mathrm{~kg} / \mathrm{batch}, 3.48$ $\mathrm{kg} / \mathrm{batch}$, and $0.25 \mathrm{~kg} / \mathrm{batch}$ respectively. Defect product on Filling - packaging process occurred due to machine idling and operator's un-optimal speed. These causes will affect the viscosity of the product blend to be out of standard. Defect product on cooking process occurred due to the amount of product that had high viscosity before it was transferred to the filling area. The un-standard viscosity of the product is mainly caused by the high moisture content in the product. Defect on packing process occurred due to the stuck conveyor that causes the product is damaged (in form and packaging). The chart of defect product summary is shown in the Fig. 3.

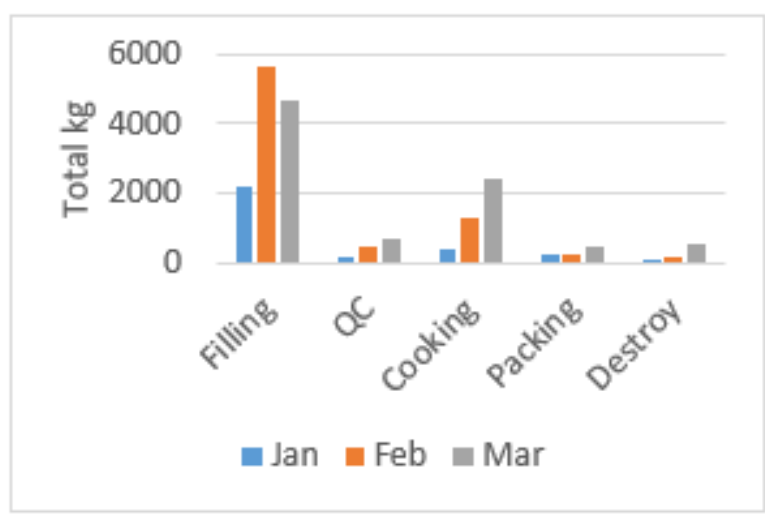

Fig. 3 Data of total defect product

\section{3) Heat loss}

Heat loss is taken into account as energy utilized during cooking and cleaning process. Heat loss is to measure the rate of heat transfer from the steam supply system through existing piping insulation. The calculation of heat loss through piping follows the principle of heat transfer through cylinder shells which consider thermal resistance all the way from the center of the whole cylinder to the outdoors. The thermal resistance network consists of conduction and convection in series [15]. The rate of heat transfer under steady conditions as expressed with formula as follow:

$$
Q=\frac{T_{a}-T_{u}}{R_{\text {total }}}
$$

$$
\begin{array}{ll}
\mathrm{Q} & =\text { Heat transfer rate }(\mathrm{W}) \\
\mathrm{T}_{\mathrm{a}} & =\text { Steam temperature }\left({ }^{\circ} \mathrm{C}\right) \\
\mathrm{T}_{\mathrm{u}} & =\text { Room temperature }\left({ }^{\circ} \mathrm{C}\right) \\
\mathrm{R}_{\text {total }} & =\text { Total thermal resistance }\left({ }^{\circ} \mathrm{C} / \mathrm{W}\right)
\end{array}
$$

The construction of the piping system in this company consists of three layers, which are the inner pipe surface, followed by the Rockwool-based insulator, and then the outer surface layer which is made from aluminum. The loss is calculated by determining the flow of heat transfer all the way from inside the pipe to the environment through 3 layers of different material. Each material has the different thermal conductivity which implicates to the ability of heat transfer occurred. The Fig. 4. below shows the schematic insulation system.

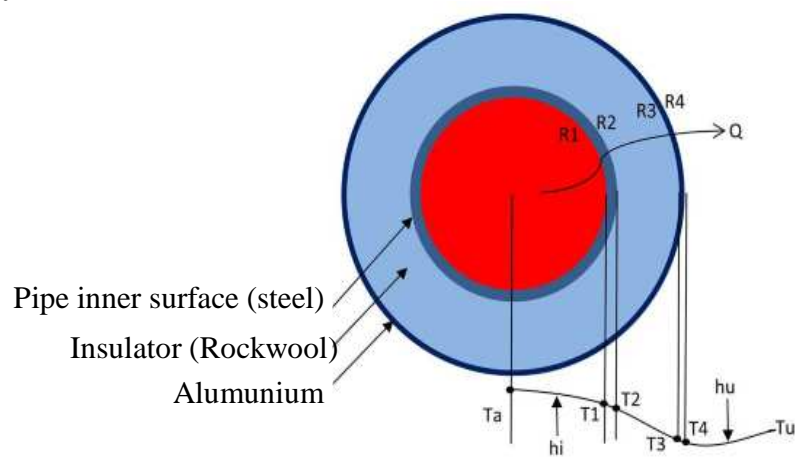

Fig. 4 Insulation system

Heat transfer rate was calculated using information regarding insulation surface temperature, the thermal conductivity of each material, and steam mass flow. Amount of actual energy generated from heat loss during cooking and cleaning process was determined by using total cycle time of each process through the specified period. Table 3 below is the summary of the current condition of insulation heat loss on both cooking and cleaning process.

TABLE III

CURRENT INSULATION HEAT LosS OF A41 PROdUCtion

\begin{tabular}{|l|l|l|}
\hline \multicolumn{1}{|c|}{ Indicator } & \multicolumn{1}{c|}{ Value } & \multicolumn{1}{c|}{ Unit } \\
\hline Rate of heat loss & 730.273 & $\mathrm{~J} / \mathrm{s}$ \\
\hline Loss on cooking & 2488945.285 & MJ \\
\hline Loss on cleaning & 12268.585 & MJ \\
\hline
\end{tabular}

\section{Root Cause of Failure}

Focus on determining the root cause of failure was conducted in speed loss and total defect product metric. Five

\begin{tabular}{|c|c|}
\hline Problem Identified & Root cause of failure \\
\hline $\begin{array}{l}\text { Delay and defect due } \\
\text { to high viscosity issue }\end{array}$ & $\begin{array}{l}\text { Instability condition on curd cheese } \\
\left(\mathrm{RC}_{1}\right)\end{array}$ \\
\hline \multirow{5}{*}{$\begin{array}{l}\text { Delay and defect due } \\
\text { to the minor stoppage } \\
\text { on filling - packaging }\end{array}$} & $\begin{array}{l}\text { Different speed specification between } \\
\text { speed controller and motor }\left(\mathrm{RC}_{2}\right)\end{array}$ \\
\hline & $\begin{array}{l}\text { Lack of operator that understands } \\
\text { machinery inspection }\left(\mathrm{RC}_{3}\right)\end{array}$ \\
\hline & New operator exists $\left(\mathrm{RC}_{4}\right)$ \\
\hline & $\begin{array}{l}\text { Ink clumped on the coding machine } \\
\left(\mathrm{RC}_{5}\right)\end{array}$ \\
\hline & $\begin{array}{l}\text { Proper spray holder is not installed } \\
\left(\mathrm{RC}_{6}\right)\end{array}$ \\
\hline \multirow{2}{*}{$\begin{array}{l}\text { Delay and defect on } \\
\text { cooling - packing }\end{array}$} & $\begin{array}{l}\text { Product with torn packaging is not } \\
\text { removed }\left(\mathrm{RC}_{7}\right)\end{array}$ \\
\hline & Conveyor belt loses $\left(\mathrm{RC}_{8}\right)$ \\
\hline \multirow{2}{*}{$\begin{array}{l}\text { Start-finish production } \\
\text { delay }\end{array}$} & Operator disciplinary $\left(\mathrm{RC}_{9}\right)$ \\
\hline & $\begin{array}{l}\text { Control on production is not } \\
\text { optimum }\left(\mathrm{RC}_{10}\right)\end{array}$ \\
\hline \multirow{3}{*}{$\begin{array}{l}\text { Cleaning process } \\
\text { reduced-speed }\end{array}$} & Operator disciplinary $\left(\mathrm{RC}_{9}\right)$ \\
\hline & $\begin{array}{l}\text { Jet spray machine is out of order } \\
\left(\mathrm{RC}_{11}\right)\end{array}$ \\
\hline & $\begin{array}{l}\text { Preparation of chemical material is } \\
\text { not done as scheduled }\left(\mathrm{RC}_{12}\right)\end{array}$ \\
\hline
\end{tabular}
main problems need to be considered, which are shown in the Table 4.

TABLE IV

SUMMARY OF ROOT CAUSE ANALYSIS 
RPN was calculated by multiplying the questionnaire response of severity, occurrence, and detectability. The Fig. 5 . below shows the distribution of RPN values.

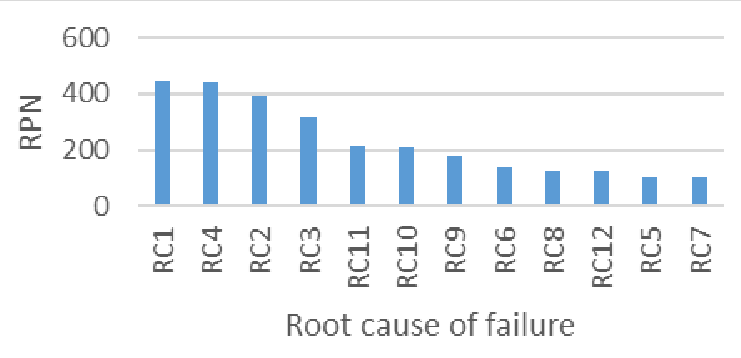

Fig. 5 The distribution of risk priority number (RPN)

Improvement of economic category focused on reducing speed loss and defect on two processes, which are filling packaging and cooling packing, and reducing speed loss on cleaning. Table 5 shows the suggestion of failure.

\section{TABLE V}

Future SugGestion OF FAILURE RoOT CAUSE

\begin{tabular}{|c|c|}
\hline Root cause & Suggestion \\
\hline $\begin{array}{l}\text { Different speed } \\
\text { specification between } \\
\text { speed controller and motor } \\
\left(\mathrm{RC}_{2}\right)\end{array}$ & $\begin{array}{l}\text { Change spare part with } \\
\text { consideration of machine } \\
\text { specification }\end{array}$ \\
\hline $\begin{array}{l}\text { Lack of operator that } \\
\text { understands machinery } \\
\text { inspection }\left(\mathrm{RC}_{3}\right)\end{array}$ & $\begin{array}{l}\text { Conduct intensive autonomous } \\
\text { maintenance training to give a } \\
\text { deep understanding of } \\
\text { machinery inspection }\end{array}$ \\
\hline New operator exists $\left(\mathrm{RC}_{4}\right)$ & $\begin{array}{l}\text { Conduct intensive On-Job } \\
\text { Training on new-hired operators } \\
\text { and increase production control }\end{array}$ \\
\hline $\begin{array}{l}\text { Ink clumped on the coding } \\
\text { machine }\left(\mathrm{RC}_{5}\right)\end{array}$ & $\begin{array}{l}\text { Perform coding machine } \\
\text { cleaning during the cleaning } \\
\text { process }\end{array}$ \\
\hline $\begin{array}{l}\text { Proper spray holder is not } \\
\text { installed }\left(\mathrm{RC}_{6}\right)\end{array}$ & Install proper spray holder \\
\hline $\begin{array}{l}\text { Product with torn } \\
\text { packaging is not removed } \\
\left(\mathrm{RC}_{7}\right)\end{array}$ & $\begin{array}{l}\text { Increase production control to } \\
\text { packaging operator regarding } \\
\text { the damaging impact of torn } \\
\text { packaging }\end{array}$ \\
\hline Conveyor belt loses $\left(\mathrm{RC}_{8}\right)$ & $\begin{array}{l}\text { Conduct preventive maintenance } \\
\text { on the conveyor as scheduled }\end{array}$ \\
\hline Operator disciplinary $\left(\mathrm{RC}_{9}\right)$ & $\begin{array}{l}\text { Manage reward for best } \\
\text { achievement in each process } \\
\text { division }\end{array}$ \\
\hline $\begin{array}{l}\text { Jet spray machine is out of } \\
\text { order }\left(\mathrm{RC}_{11}\right)\end{array}$ & $\begin{array}{l}\text { Repair the jet spray to reduce } 30 \\
\text { minutes of cleaning time }\end{array}$ \\
\hline $\begin{array}{l}\text { Preparation of chemical } \\
\text { material is not done as } \\
\text { scheduled }\left(\mathrm{RC}_{12}\right)\end{array}$ & $\begin{array}{l}\text { Conduct chemical material } \\
\text { preparation before the cleaning } \\
\text { process starts }\end{array}$ \\
\hline
\end{tabular}

The summary of the improvement proposed can be seen in the Table 6 as follow.

TABLE VI

FUTURE-STATE IMPROVEMENT OF ECONOMICAL CATEGORY

\begin{tabular}{|l|l|l|}
\hline \multicolumn{1}{|c|}{ Indicator } & \multicolumn{1}{c|}{ Value } & \multicolumn{1}{c|}{ Unit } \\
\hline Production lead time & 4759.17 & seconds \\
\hline Cleaning lead time & 2.14 & hour \\
\hline Total defect product & 2.82 & $\mathrm{~kg} / \mathrm{batch}$ \\
\hline
\end{tabular}

\section{Life Cycle Assessment}

In this stage, further environmental performance analysis was conducted using the gate-to-gate approach of the life cycle assessment. The analysis consists of several main steps that begin with determining goal and scopes, analyzing life cycle inventory, assessing environmental impacts, analyzing for future improvement. The analysis considered the inventory input from electricity usage, the steam loss generated, process water usage, chemical material usage, and packaging material. All the input has the possibility of causing environmental impact with three-damage category, which are damage to human health, ecosystem quality, and resources. The inventory was added as the input of environmental assessment, and the output of assessment was calculated using Simapro v. 8.0 software. The output is presented as a single score with Point $(\mathrm{Pt})$ as the unit to represent the environmental impact. It is shown in Table 7.

TABLE VII

Single SCORE OF CURRENT DAMAge CATEGORIES

\begin{tabular}{|l|l|l|l|l|}
\hline \multirow{2}{*}{ Process } & \multicolumn{4}{|c|}{ Damage Category (Pt) } \\
\cline { 2 - 5 } & $\begin{array}{l}\text { Human } \\
\text { Health }\end{array}$ & $\begin{array}{l}\text { Ecosystem } \\
\text { Quality }\end{array}$ & Resources & Total \\
\hline Unwrapping & 37.5 & 0.17 & 1.65 & 39.4 \\
\hline Grinding & 1210 & 5.45 & 52.9 & 1260 \\
\hline Cooking & 48900 & 840 & 11400 & 60700 \\
\hline $\begin{array}{l}\text { Cooling- } \\
\text { packing }\end{array}$ & 5920 & 26.8 & 259 & 6200 \\
\hline Palletizing & 1130 & 5.09 & 49.4 & 1180 \\
\hline Cleaning & 55.1 & 3.93 & 51.3 & 108 \\
\hline
\end{tabular}

\section{E. Improvement of LCA Scenario}

Improvement of life cycle assessment focused on reducing environmental impacts on heat loss generated due to insulation system. The insulation condition that is currently being used by the company to flow steam on A41 production is Rockwool material with $42 \mathrm{~mm}$ of thickness. Rockwool is the typical material that is used on steam with intermediate temperature $\left(15^{\circ} \mathrm{C}-315^{\circ} \mathrm{C}\right)$. The loss from the pipework system is possible to be reduced by choosing the appropriate material and thickness [16]. Selecting Rockwool as insulator material in this company has met the literature suggestion since the average of steam temperature used is $150.6^{\circ} \mathrm{C}$. Rockwool has relatively same good workability with more economical cost compared to other insulation material [17]. The outer side of the insulator is covered by aluminum material with $1 \mathrm{~mm}$ of thickness. Aluminum is used on the cold side of insulation as water vapor barrier to avoid losing a certain amount of water vapor.

Focus on reducing loss is then suggested on selecting appropriate insulator thickness. The current condition of insulator thickness does not meet the requirement proposed by [16]. With the outside diameter of the steel pipe $60.3 \mathrm{~mm}$, the thermal conductivity of insulator $0.05 \mathrm{~W} / \mathrm{m}^{\circ} \mathrm{C}$, and hot face temperature $150.6^{\circ} \mathrm{C}$, the suggested thickness of the insulator is $49 \mathrm{~mm}$. Adding more thickness to the required one will surely give benefit both in an economic and environmental perspective. Based on the calculation, the heat loss can be reduced as $6.49 \%$, and the environmental impact on cooking and cleaning can be reduced by applying $49 \mathrm{~mm}$ of insulator thickness. Table 8 shows the 
environmental impact improvement addressing the application of suggested thickness.

TABLE VIII

FUTURE-STATE OF LCA SCENARIO

\begin{tabular}{|l|l|l|}
\hline \multicolumn{1}{|c|}{ Future state parameter } & \multicolumn{1}{|c|}{ Value } & \multicolumn{1}{c|}{ Unit } \\
\hline Heat loss rate & 682.897 & $\mathrm{~J} / \mathrm{s}$ \\
\hline Heat loss on cleaning & 11472.666 & $\mathrm{MJ}$ \\
\hline Heat loss on cooking & 2327476.139 & $\mathrm{MJ}$ \\
\hline $\begin{array}{l}\text { Environmental impact on } \\
\text { cleaning }\end{array}$ & 102 & $\mathrm{Pt}$ \\
\hline $\begin{array}{l}\text { Environmental impact on } \\
\text { cooking }\end{array}$ & 59500 & $\mathrm{Pt}$ \\
\hline
\end{tabular}

\section{F. Advantages and Disadvantages}

The advantage of this research is to allow lean improvement process to focus on sustainability category improvement actions and to monitor the environmental impacts during lean improvement initiatives. The disadvantage of this research are the focus analysis of triple bottom line that only considers the critical sustainability metrics, the environmental impact assessment that does not consider heat loss from other causes, and the inventory assessment that only collects last three-month performance data.

\section{CONCLUSION}

Sustainable Value Stream Mapping (Sus-VSM), with the integration of Life Cycle Assessment (LCA), evaluated manufacturing performance through sustainability, following triple bottom line perspective. Critical sustainability metrics selected using the Borda Count Method (BCM) were speed loss, total defect product, and heat loss. Speed loss focused on evaluating delay time on the following process: cooking, filling - packaging, cooling - packing, and reduced-speed on the cleaning process. Life cycle assessment was used to evaluate the environmental impact of processes. In this research. Evaluation of environmental impact focused on minimizing impacts that were caused by heat loss on pipe insulation system.

Current total lead time of production are 4967.46 seconds with total defect product on cooking, filling - packaging, and cooling - packing are $4.85 \mathrm{~kg} / \mathrm{batch}$. Reduce speed on cleaning was calculated as 0.66 hours/cleaning. Evaluation of minimizing speed loss and defect product was proposed with the future state of production lead time as 4759.17 seconds, reduced-speed of cleaning 0 hours/cleaning, and defect product $2.82 \mathrm{~kg} / \mathrm{batch}$.

Total heat loss on cooking and cleaning process was calculated to be $2488945.285 \mathrm{MJ}$ and 12 268.585 MJ respectively. Analysis of environmental impact using Simapro v. 8.0 software shows that impact for cleaning and cooking were $108 \mathrm{Pt}$ and $60700 \mathrm{Pt}$. Environmental impact on cleaning and cooking can be reduced by implementing insulation thickness $49 \mathrm{~mm}$ to meet literature standard based on UK Government's Energy Efficiency Best Practice Programme. Future environmental impact assessed can be reduced to $102 \mathrm{Pt}$ on cleaning and $59500 \mathrm{Pt}$ on cooking.

Based on the disadvantages mentioned, it is suggested to do further analysis on not only critical sustainability metrics. The heat loss calculation is more comprehensively considered as other causes. Life cycle assessment is required for measurement on a year basis to to decide further scenario that represents annual performance.

\section{ACKNOWLEDGMENT}

We would like to thank PT $\mathrm{X}$ for the occution joining the research witihin the industry.

\section{REFERENCES}

[1] A.A. Feil and D. Schreiber., "Sustainability and sustainable development: unraveling overlays and scope of their meanings," Cadernos EPABE.BR., Vol. 14 No. 3, pp. 667-681, 2017.

[2] P. N. Rao, Sustainable Manufacturing - Principles, Applications, and Directions, Cedar Falls, USA, University of Northen Iowa, 2013.

[3] M. Rojek and Nowosielska, Social Responsibility of Organization Directions of Changes, Wrocław, Poland, Publishing House of Wrocław University of Economics, 2015.

[4] M. Rother and J. Shook, Learning to See: Value Stream Mapping to Add and Eliminate Muda, Massachusetts, USA, The Lean Enterprise Institute, 1999

[5] W. Faulkner and F. Badurdeen, "Sustainable value stream mapping (Sus-VSM): methodology to visualize and assess manufacturing sustainability performance," Journal of Cleaner Production, 30, pp. 1-11, 2014.

[6] S. Vinodh, B. Ruben and P. Asokan, "Life cycle assessment integrated value stream mapping framework to ensure sustainable manufacturing: a case study," Clean Techno Environ Policy. Springer, 2015.

[7] [GFN] Global Footprint Network, "Glossary," http://www.footprintnetwork.org (Accessed 2 July 2018)

[8] B. Meng and M. Dong, "Research on the lean process reengineering based on value stream mapping for Chinese enterprise," Management Science and Engineering, Vol. 6 No.2, pp. 103-106, 2012.

[9] D. Locher, Value Stream Mapping for Lean Development: A How-to Guide for Streamlining Time to Market. New York, USA, CRC Press, 2008

[10] University of California Davis, "Thinking lean," http://oe.ucdavis.edu/Lean/Lean\%20Mini\%20Conf_10192015_web\%20version.pdf (Accessed 26 July 2018)

[11] M. A. Zahid and H. de Swart, "The Borda majority count," Inform. Sci. Vol. 295, pp. 429-440, 2015.

[12] B. Andersen and T. Fagerhaud, Root Cause Analysis: Simplified Tools and Techniques, Milwaukee, USA, Quality Press, 2006.

[13] [FFW] Fuel from Waste, "LCA scope and analyzed system boundaries," http://www.fuelfromwaste.eu/download.html (Accessed 27 July 2018).

[14] PRé., "The Eco-indicator 99: A damage-oriented method for Life Cycle Impact Assessment," Product Ecology Consultant, 2001.

[15] Y. A. Cengel and A. J. Ghajar, Heat and Mass Transfer, New Delhi, India, Tata McGraw Hill Education Private Limited, 2013.

[16] [CIBSE] Chartered Institution of Building Services Engineers, "The economic thickness of insulation for hot pipes," http://www.cibse.org/getmedia/3c90596e-89e7-437c-989a (Accessed 13 May 2018).

[17] [TIAC] Thermal Insulation Association of Canada, "Mechanical insulation best practices guide," http://www.tiac.wa/wpcontent/uploads (Accessed 15 May 2018). 